\title{
STRUCTURAL RESTORATION AND RE-USE OF THE HISTORIC COAL MINE TOWER
}

\author{
DAVID ANĐIĆ ${ }^{1 *}$, MATEJ HORVAT ${ }^{2}$ AND JURAJ POJATINA ${ }^{2}$ \\ ${ }^{1}$ Studio Arhing d.o.o. \\ Ćire Truhelke 49, 10000 Zagreb, Croatia \\ e-mail: david.andjic@yahoo.com,www.studio-arhing.hr \\ ${ }^{2}$ Studio Arhing d.o.o. \\ Ćire Truhelke 49, 10000 Zagreb, Croatia \\ e-mail: horvat.matej1@gmail.com, juraj.pojatina@gmail.com,www.studio-arhing.hr
}

Keywords: historical structure, steel, mine tower, reconstruction

\begin{abstract}
The coal mine is located in the town of Labin, Istria peninsula, Croatia. Restoration of the tower is a part of the project that includes thorough restoration and re-use of the Labin mining complex for cultural, tourist and educational purposes. The tower was built in 1938 by Italian authorities as part of the pre-war campaign. It is a $32.5 \mathrm{~m}$ high steel structure that once enveloped the elevator to a $200 \mathrm{~m}$ deep mine shaft. The structure is a built up Vierendeel truss with four columns / chords connected with horizontal moment resistant beams. Two large steel inclined struts were resisting elevator rope forces connected to the elevator machine building. The mine was shut down in 1988. The assessment of the tower consisted of geometry measurement, cross-section shape determination, steel quality determination, condition of members and connections (rivets and bolts), protective coating condition and underground supports condition. Two samples were taken to laboratory to determine the steel grade with tensile yield test. Structural model with existing members has also been analysed. Different loads were considered comparing the original purpose of the tower and the planned representational purpose. In addition, structural member verification according to Eurocode standards has been done. Load bearing steel structure is geometrically sound, mostly with no visible deformations, deflections or drifts. Foundations are crack free and with no visible subsiding. Lack of maintenance of the anticorrosive coating from 1988 until today caused most of the damage. Due to the significantly aggressive environment, anchoring part of the structure was severely ruined. Lower part of the above ground structure was in the similar condition. Water retention and salt carried from the lower part of the shaft caused significant damage to the steel structure in these areas. Replaced members were built in with original riveting technique. Anchoring structure replacement called for a temporary support structure, which represented the most demanding operation in the whole restoration process. The temporary support structure was a steel truss structure in pyramidal form that allowed complete removal of the lowest segment and reconstruction of the anchoring elements and concrete foundation. According to the evaluation, existing galleries that surrounded the tower had to be completely removed and redesigned with new loads. Future use of the tower with its galleries is primarily of representational purpose. Moreover, a new elevator with its own structure inside the existing tower is considered and it has no influence on the existing
\end{abstract}


structure. Since the tower is registered as an architectural heritage by the Croatian Ministry of Culture, specific demands regarding structural restoration were issued. The principles of structural analysis and restoration together with multidisciplinary approach have been applied in this project.

\section{INTRODUCTION}

The coal mine is located in Istrian town of Labin, region that was well known for its mining potential in the past. The tower was built in 1938 by Italian authorities as part of the pre-war campaign. Shaft above which the tower was built was part of the underground complex with pertaining tunnels and shafts that connected nearby mining towns and small ports in that region. The mine was shut down in 1988 and tower rests unused and exposed to weather conditions since then. Restoration of the tower was part of the project that included thorough restoration and re-use of the Labin mining complex for cultural, tourist and educational purposes.
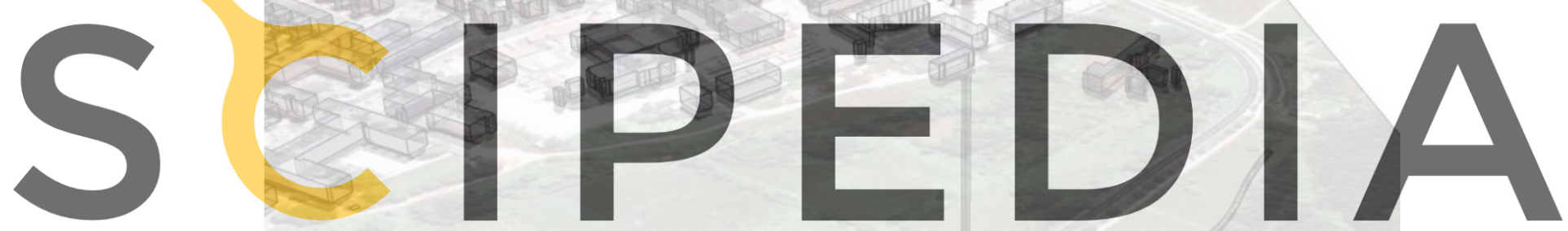

Register for free at https//www.scipedia.com to download the version without the watermark

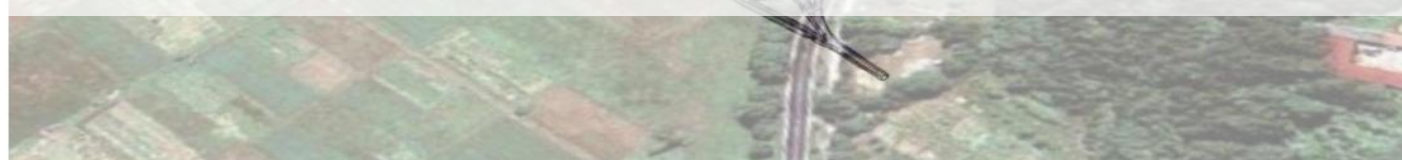

Figure 1: Mine shaft with nearby tunnels $200 \mathrm{~m}$ below the surface

Structural restoration of the tower included replacement of corroded members of underground anchoring structure and lower part of the above ground structure which sustained damage too severe to be repaired. Temporary support structure was built to enable removal of the lowest segment and reconstruction of the anchoring elements and concrete foundation. Replaced members were built in with original riveting technique. Existing galleries that surrounded the tower had to be completely removed and redesigned. Installation of the new elevator that leads $200 \mathrm{~m}$ down the shaft was also a part of the restoration project in conceptual design phase. The new structure of the elevator inside the existing tower has no influence on the tower structure. 

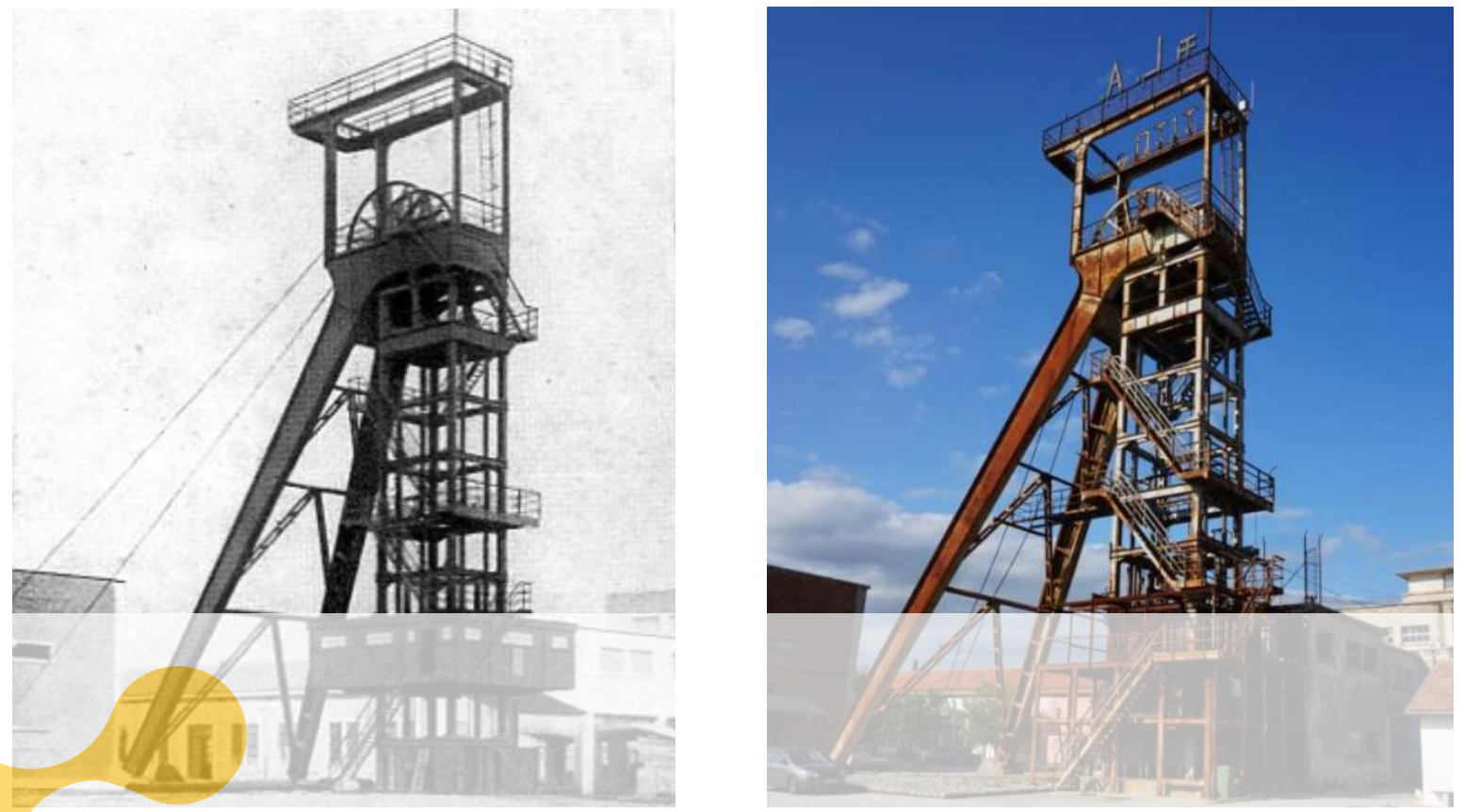

Figure 2: Mine tower and the connecting bridge, as originally built - photo taken in 1942. on the left, mine tower nearly 30 years after shutting down - photo taken in 2015. on the right
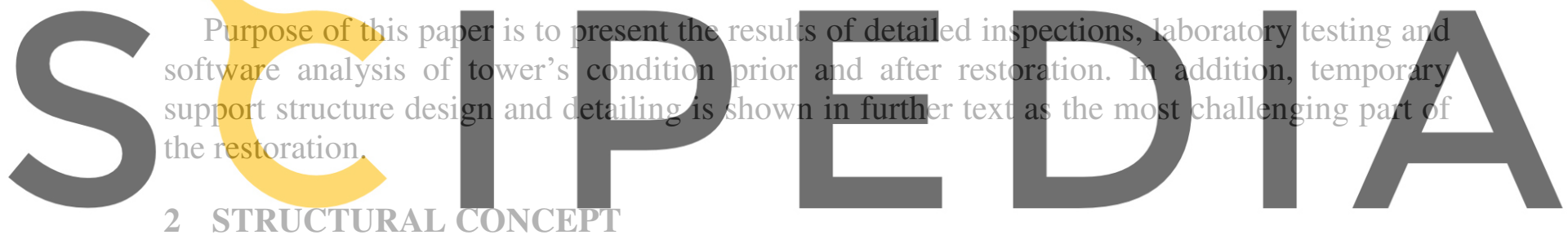

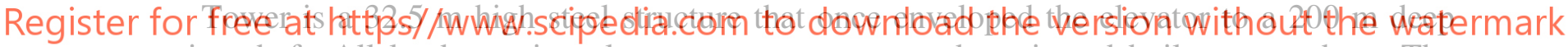
mine shaft. All load carrying elements were constructed as riveted built up members. The structure is a built up Vierendeel truss with four columns/chords connected with horizontal moment resistant beams. The tower itself is anchored beneath terrain to the steel transfer beams which directed reactions to the concrete wall of the shaft. Vertical truss structure is $22.0 \mathrm{~m}$ high. Layout dimensions of the truss are $4.5 \times 3.7 \mathrm{~m}$ - Vertical distance between horizontal beams is $2.4 \mathrm{~m}-3.0 \mathrm{~m}$. Inclined part of the structure is connected to the main truss through the pinned joint at the top of the truss and anchored in the concrete footing with bolts. Inclined struts resisted the elevator rope forces connected to the elevator machine building. $\mathrm{K}$ form bracing is installed in plane of the struts. On the horizontal top part of the struts, at the height of $24.2 \mathrm{~m}$ two pulley wheels (sheaves) with the diameter of 5,0 m were installed. Wheels were constructed as riveted and welded built up members. The top structure above pulley wheels is 7,0 meters high and consists of four columns connected at their top with beams with the inspection deck. Gallery with 2,0 m wide walking deck surrounded the tower at the height of $+4.65 \mathrm{~m}$ above the terrain level with layout dimension $8.4 \times 7.6 \mathrm{~m}$. Its primary function was to enable communication with miners' building and their transportation via elevator. Steel stairway with pertaining platforms served for inspection and maintenance. It 
started at the base of the tower and reached the sheaves level from where the vertical ladder led to the inspection deck on top.

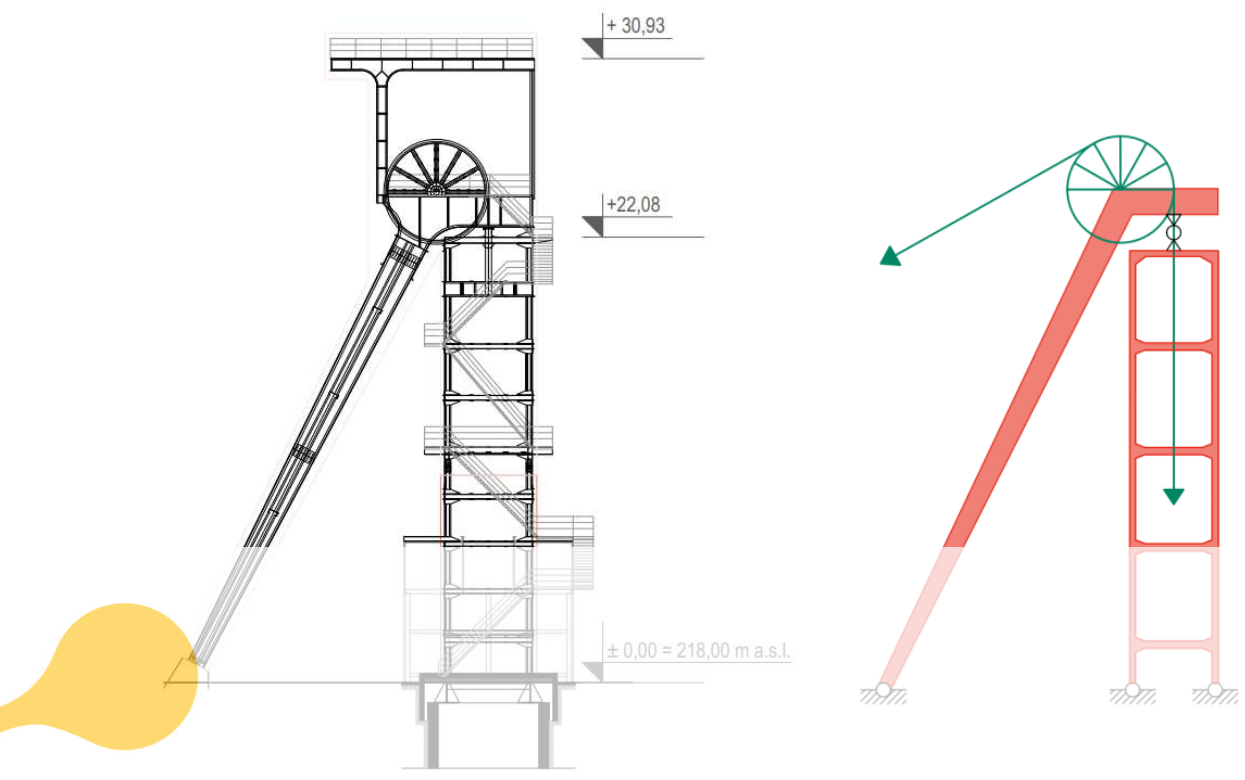

Figure 3: Mine tower drawing prior to restoration on the left, structural scheme with the forces imposed by the elevator mechanism on the right
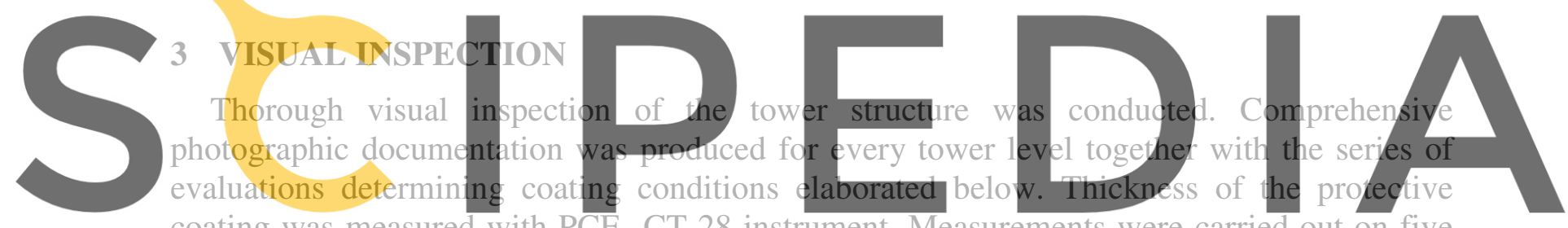

coating was measured with PCE- CT 28 instrument. Measurements were carried out on five

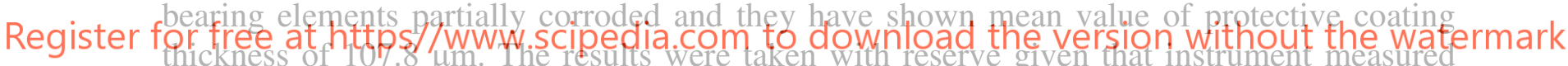

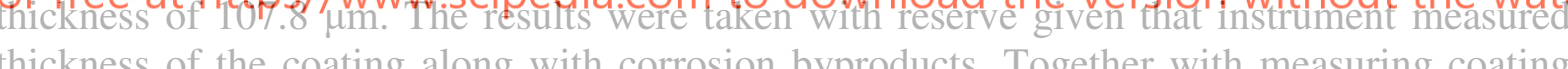

thickness, cross hatch adhesion test was conducted with Elcometer 107 cross hatch cutter. Results showed that structure elements above level $+11.70 \mathrm{~m}$ fall into class 2 and elements below into class 4 determined by ISO 2409 standard. Furthermore, evaluation of the degradation of the coating was made according to standards HRN EN ISO 4628-(2-6).

Table 1: Assesed degree of degradation according to standardards HRN EN 4628-(2-6)

\begin{tabular}{|l|c|c|}
\hline \multirow{2}{*}{\multicolumn{1}{c|}{ Standard }} & \multicolumn{2}{|c|}{ Structure level } \\
\cline { 2 - 3 } HRN EN ISO 4628- & Above $+11.70 \mathrm{~m}$ & Below $+11.70 \mathrm{~m}$ \\
\hline-2 Blistering & $4(\mathrm{~S} 5)$ & $5(\mathrm{~S} 5)$ \\
\hline-3 Rusting & Ri 3(S3-5) and Ri 4(S4-5) & Ri 5(S5) \\
\hline-4 Cracking & $3(\mathrm{~S} 4) \mathrm{c}$ & $5(\mathrm{~S} 5) \mathrm{b}$ \\
\hline-5 Flaking & $4(\mathrm{~S} 4) \mathrm{b}$ & $5(\mathrm{~S} 5)$ \\
\hline-6 Chalking by tape method & $2(\mathrm{~S} 2)$ & \\
\hline
\end{tabular}


It was concluded that the underground support structure and the lower part of the structure were in extremely deteriorated condition. Therefore, these sections were selected for complete or partial replacement. Members of the upper part of the structure were selected for restoration of the protective coating and minimal repair actions.
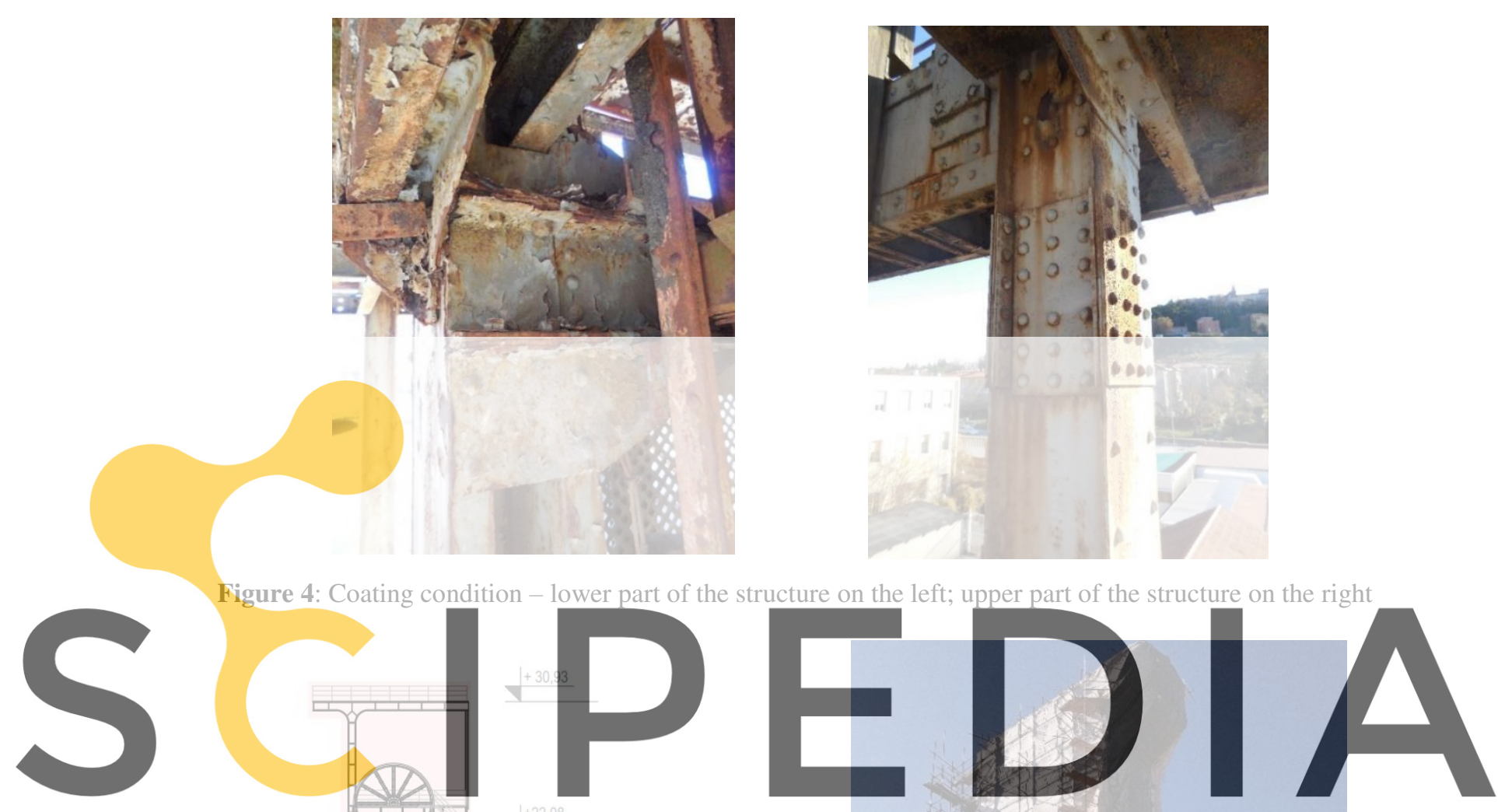

Register for free at https//WwWw.scipedia.com to download the version without the watermark

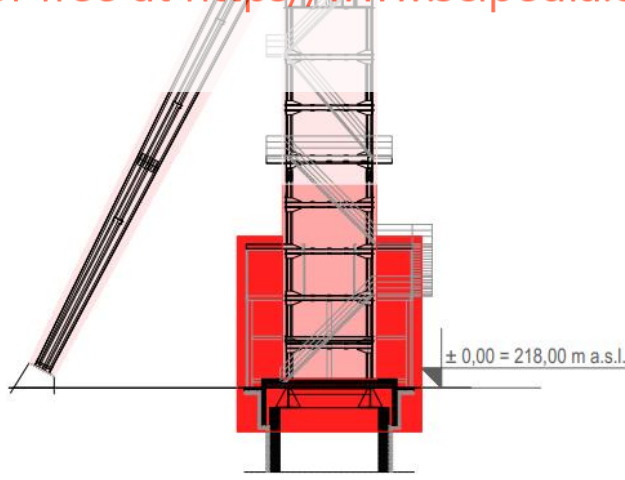

restoration of protective coating

minimal repair actions on main structure elements

partially replaced structure elements

completely replaced structure elements

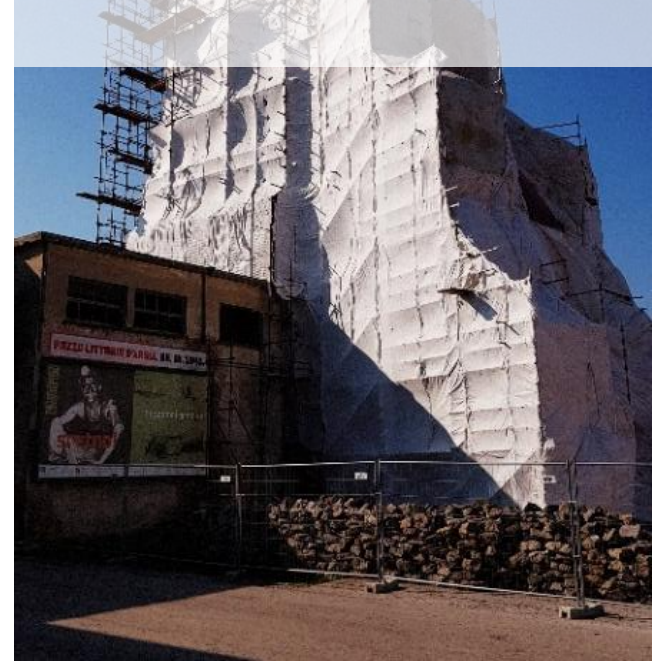

Figure 5: Structure defects and repair actions classification on the left; tower during sandblasting of the upper part of the structure on the right 


\section{LABORATORY TESTING}

In addition to the on-field inspection, tensile test and chemical analysis in laboratory were conducted. The specimens were taken from the field into laboratory for analysis. Although specimens satisfy tensile test for hot rolled type of steel S235 in line with EN 10025:2002, toughness not being tested, chemical analysis has shown that the concentration of impurities is higher than allowed - concentration of $\mathrm{P}, \mathrm{S}$ and $\mathrm{Cu}$, respectively. Taking the results of chemical analysis into account together with age of structure, built in 1938., specimens fall into St33 type of steel according to DIN 17100, unkilled steel. The aforementioned type of steel matched S185 type of steel according to HRN EN 10025 with remark that lesser welding capability should be taken into account when choosing welding technology. Therefore, only bolted connections were used.

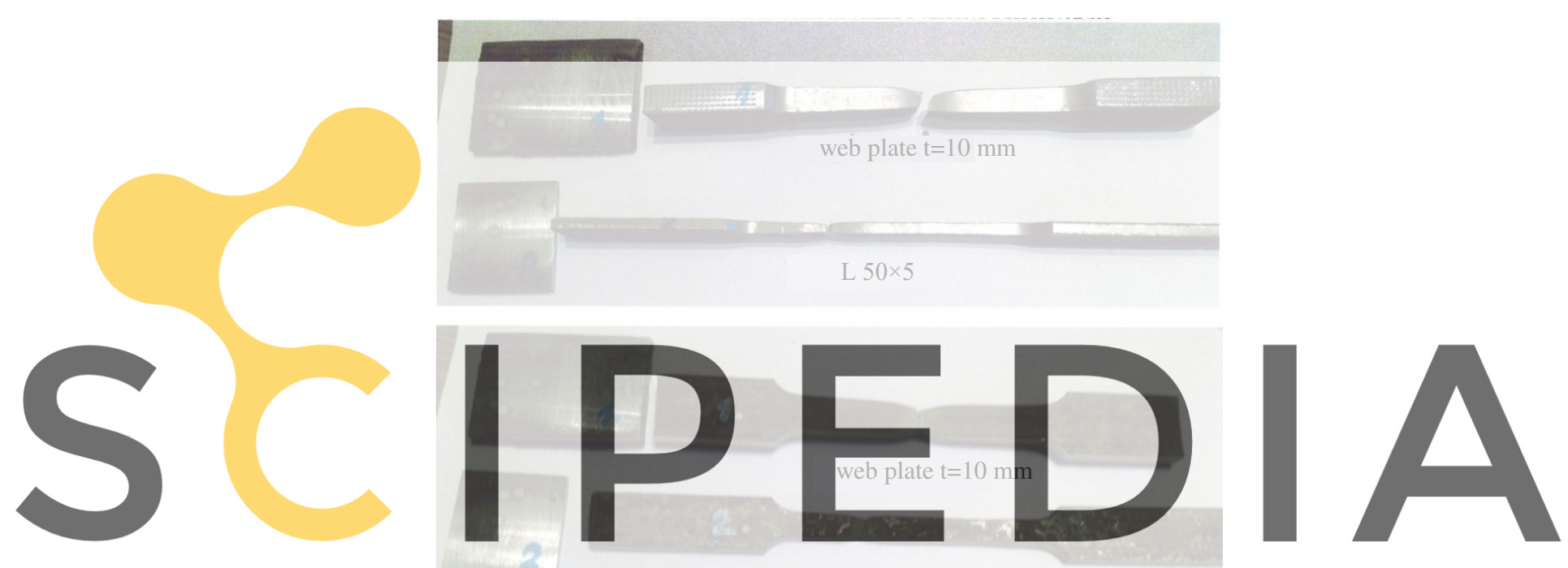

Register for free at https//www.scipedia.com to download the version without the watermark

Figure 6: Specimens for chemical analysis on the left and tensile test specimens on the right

Table 2: Results of tensile test

\begin{tabular}{|c|c|c|c|c|c|c|c|}
\hline $\begin{array}{c}\text { Specimen } \\
\text { No. }\end{array}$ & $\begin{array}{c}\text { Specimen } \\
\text { description }\end{array}$ & $\begin{array}{c}\text { Assumed } \\
\text { class of } \\
\text { material }\end{array}$ & $\begin{array}{c}\text { Cross } \\
\text { sectional } \\
\text { area of the } \\
\text { specimen } \\
(\mathrm{mm})\end{array}$ & $\begin{array}{c}\text { Elastic limit } \\
\text { (yield } \\
\text { strength) } \\
\mathrm{R}_{\mathrm{e}} \\
\left(\mathrm{mm}^{2}\right)\end{array}$ & $\begin{array}{c}\text { Tensile } \\
\text { Strength } \\
\left(\mathrm{N} / \mathrm{mm}^{2}\right)\end{array}$ & Strain & Remark \\
$\mathrm{R}_{\mathrm{m}}$ & $\mathrm{A}_{5}$ & $\left(\mathrm{~N} / \mathrm{mm}^{2}\right)$ & $(\%)$ & min. 26 & \\
\hline 1 & $\begin{array}{c}\text { Legitimate for S235 JR } \\
10 \mathrm{~mm}\end{array}$ & St 33 & 50 & 256 & 368 & 29 & \\
\hline 2 & L=50x5mm & St 33 & 141 & 249 & 357 & 45 & \\
\hline
\end{tabular}




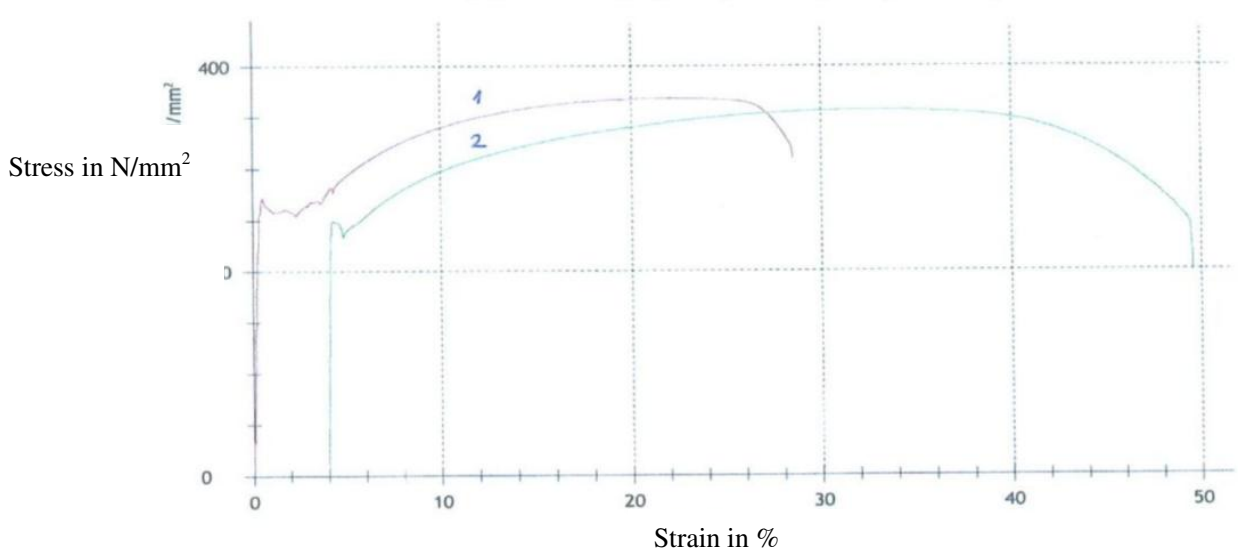

Figure 7: Stress- strain diagram for tested specimens

Table 3: Results of chemical analysis on LECO spectrometer

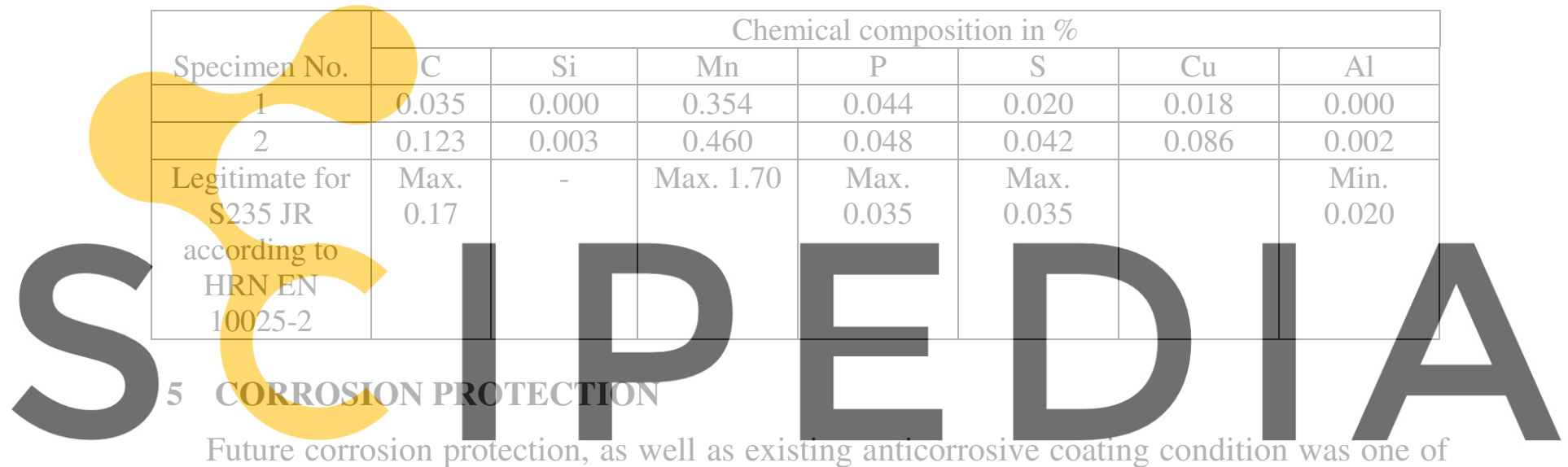

Future corrosion protection, as well as existing anticorrosive coating condition was one of the main concerns at the time of the inspection. Due to the condition of the coating, especially

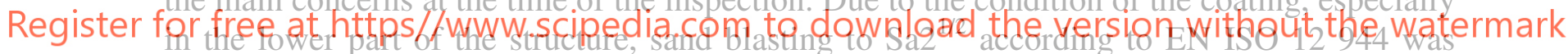

proposed. Execution and supervision of the protective coating was done according to EN ISO 12944-1-8:1999. Atmospheric corrodibility category was determined as C5 very high (80-200 $\mu \mathrm{m}$ for a year of exposure). Anticorrosive protection coating was proposed as a combination of two component priming coat with high zinc share (80 $\mu \mathrm{m}$ NDFT), epoxy based intermediate coats $(80 \mu \mathrm{m}$ NDFT) and polyurethane topcoat (80 $\mu \mathrm{m}$ NDFT). Overall nominal dry film thickness was designed as $240 \mu \mathrm{m}$.

\section{STRUCTURAL ANALYSIS}

Structural analysis of existing tower structure was performed with reduced (actual) crosssection dimensions and according to Eurocode standards with loads predicted for the future use. Imposed loads were significantly smaller compared to the loads that the tower was initially built for. Influence of the horizontal loads, wind and seismic loading, was taken into account during design checks. Analysis of the members had shown sufficient load bearing capacity. As the most challenging part of the restoration, temporary structure that enabled reconstruction and replacement of severely damaged sections of the tower, was further elaborated. 


\subsection{Temporary support structure}



Figure 8: Temporary support structure model on the left; diagrams of longitudinal forces on temporary truss

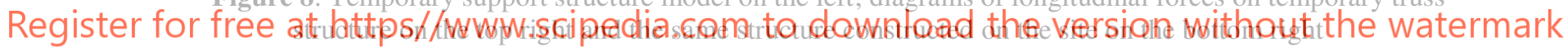

As part of the reconstruction, temporary support structure was designed. Neighbouring structure and existing roads around the site also determined the final outline of the temporary structure. Steel space truss in the form of truncated pyramid was chosen as the optimal structure for given purpose. Truss elements were bolted with circular hollow sections $273.1 \times 10.0 \mathrm{~mm}$.

Transfer of the gravitational and horizontal loads from tower to temporary structure was enabled via bolted connection. Forces between two structures were transmitted through 24 M24 bolts and $20 \mathrm{~mm}$ thick plate with side stiffeners into the members of the temporary truss structure. 

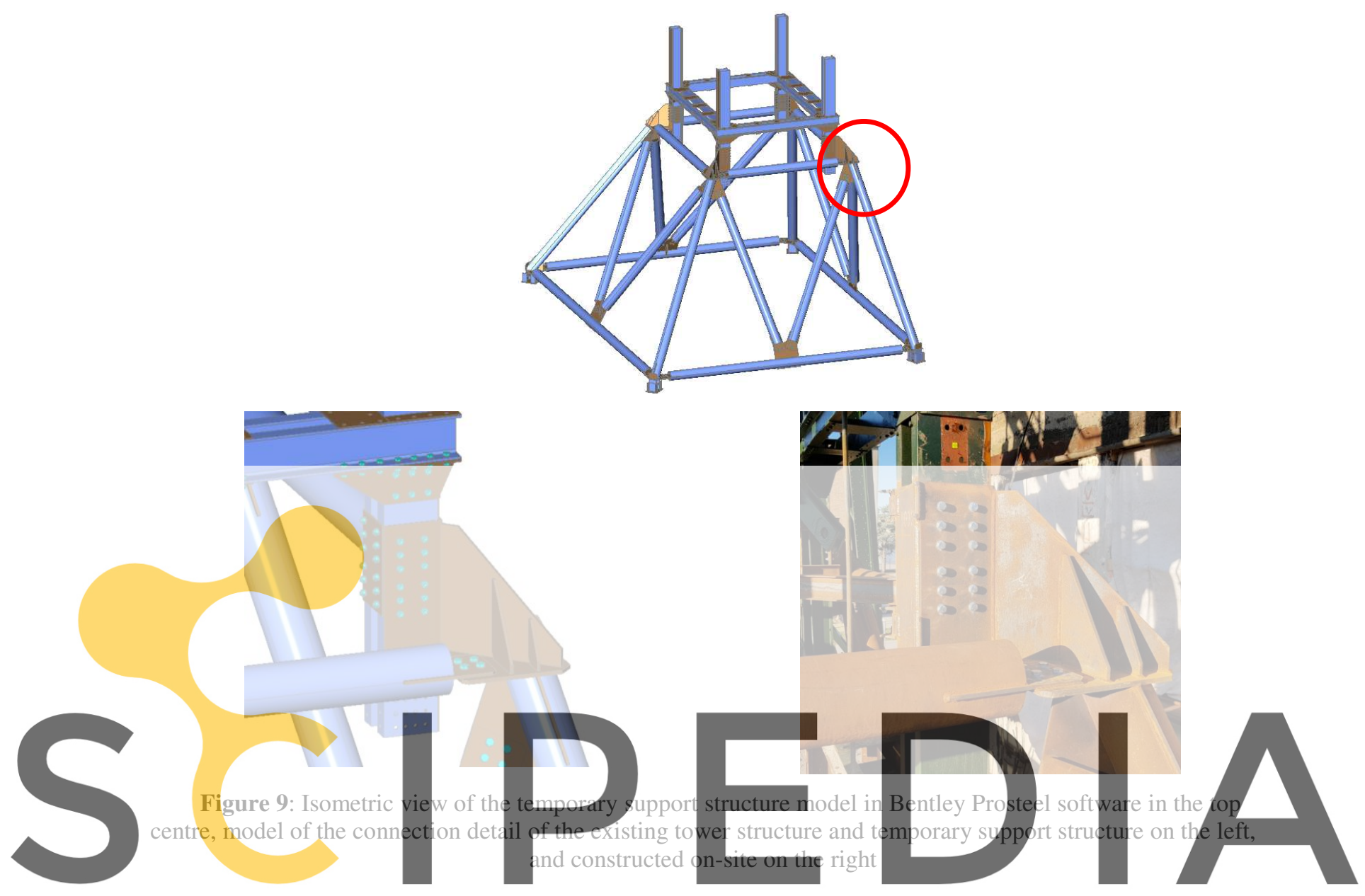

Hydraulic pump was installed in the steel bearing connection. Pumps enabled lifting, load

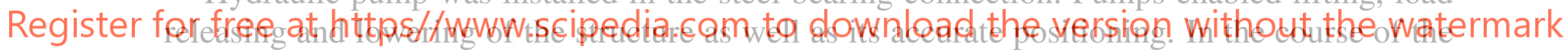
design of the temporary structure it was important to properly assign boundary conditions of the supports. Three out of four bearings were designed as movable in horizontal directions while fourth bearing was fixed so the forces in members of the truss could be correctly triggered.
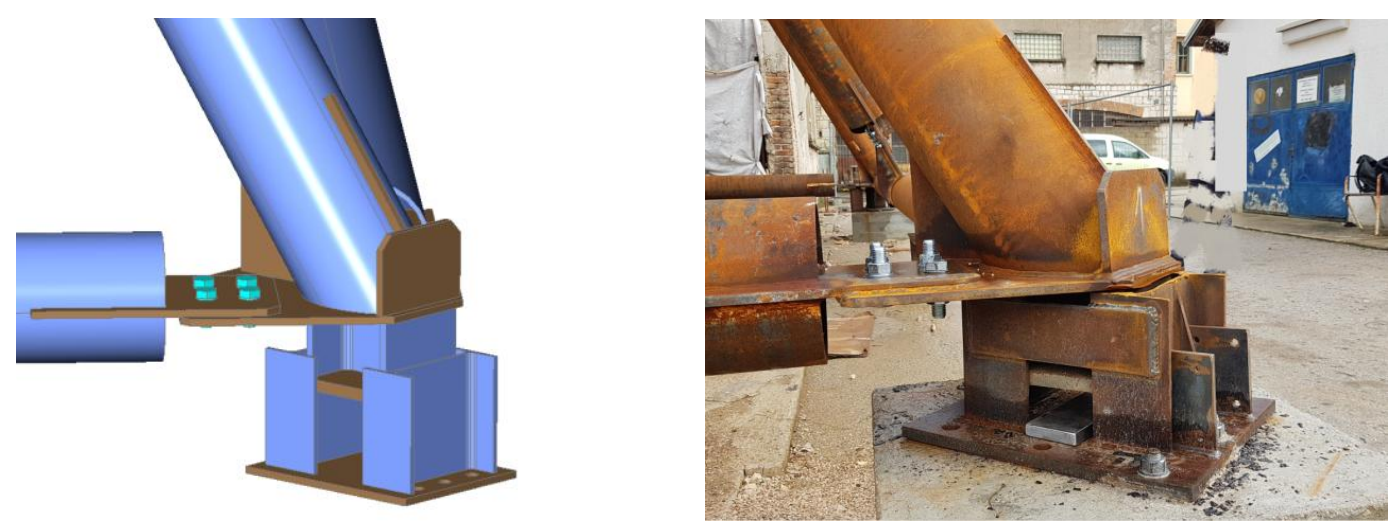

Figure 10: Software design of the steel bearing connection on the left and construted on-site in the right 


\section{CONCLUSION/RECONSTRUCTION PHASE}

The tower structure was severely deteriorated due to years of negligence, deficiency of protective coating and significantly aggressive environment of the underground structure. The principles of structural analysis and restoration of historic steel structures together with a multidisciplinary approach was applied in this project. In addition, unique temporary structure that allowed replacement of the base of the tower was designed and successfully constructed. The next phase of the restoration project is elevator installation.

\section{REFERENCES}

[1] J. Pojatina, "Existing structure assessment and analysis", (2015).

[2] J. Pojatina, "Coal mine tower restoration and new elevator design", (2016).

[3] J. Pojatina, "Structural restoration of coal mine tower", (2018).

[4] J. Radić, Trajnost konstrukcija 1, Croatian University Edition, 2010

[5] A. Braun, T. Vidović, D. Bačić, "Coal-mining plant Pozzo Littorio near Labin, unknown work of Gustavo Pulitzer Finali in Istria, Prostor. Scientific journal for architecture and urbanism, Vol. 27 No.1 (57): 1330-0652, (2019.), pp. 36-49.

[6] A. Braun, T. Vidović, Coal mining complex Pijacal, Labin-central building and export shaft, (2017.)
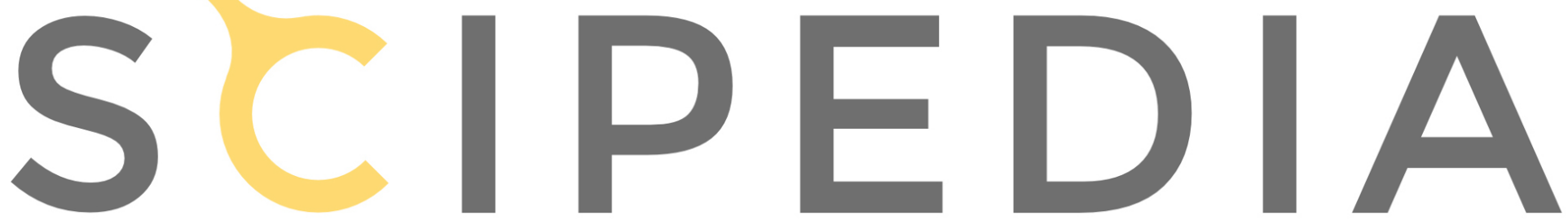

Register for free at https//www.scipedia.com to download the version without the watermark 